\title{
Role of Faculty in Promoting Lifelong Learning: Characterizing Classroom Environments
}

\author{
Susan M. Lord
}

Katharyn Nottis, Candice Stefanou, Michael Prince
John C. Chen

Jonathan Stolk

\begin{abstract}
Calls for educational reform emphasize the need for student-centered learning approaches that foster lifelong learning. To be a lifelong learner includes characteristics consistent with those of self-directed learners, such as being curious, motivated, reflective, analytical, persistent, flexible, and independent. Educational research has shown that the building of these aptitudes involves a complex interplay among nearly every aspect of human development. Instructor support of students' self-directed learning (SDL) development relies on understanding and balancing these factors in the classroom. Engineering educators play a critical role in influencing outcomes related to SDL through their design of courses that support students' transitions from controlled to autonomous learning behaviors. This study will examine a variety of engineering courses and pedagogical approaches. Each will be characterized using instructor course information, videotaped classroom observations of instructor-student and student-student interactions, student and instructor responses to surveys, and focus groups. Finally, the students' capacity for SDL will be measured using the Motivated Strategies for Learning Questionnaire. This approach should provide for rich, contextualized descriptions of what instructors and learners do, how instructors and students relate to each other, and how students view their classrooms. This work-in-progress paper will describe our initial work in this multiyear study.
\end{abstract}

Keywords-Lifelong learning, Autonomy support, Self-directed learning

\section{INTRODUCTION}

Calls for educational reform emphasize the need for student-centered learning approaches that aid development of broader skills and attitudes such as a capacity for lifelong learning $[1,2,3,4,5]$. Engineering educators as well as ABET recognize that students' development of such a capacity is vital for their success in today's global and rapidly changing engineering environment $[4,5,6]$. However, the current emphasis - particularly in the engineering education community - seems to be on assessing students' lifelong learning abilities, rather than on understanding the relationship between instructor practices and lifelong learning outcomes. To be a lifelong learner includes characteristics consistent with those of self-directed learners, such as being curious, motivated, reflective, analytical, persistent, flexible, and independent.

Designing learning environm ents and activities that engage students in self-directed learning (SDL) and foster the growth of autonomous individuals, however, is not a simple task. W ith its introduction of program outcom e (i) "a recognitio $n$ of the need for, and an ability to engage in lifelong learning," as a requirement for all engineering graduates, ABET essentially challenged engineering educators to determine how we may best engage students in SDL (and eventually lifelong learning). To effectively prom ote SD L, faculty need to be skillful in facilitating pedagogies that engage students in self-direction, be sensitive to and understand student attitudes and behaviors in SDL settings, and be aware of the roles that classroom environments can play in aiding students' SDL development.

The limited existing studies show no significant gains in undergraduate engineering students' capacity for SDL via traditional instruction $[7,8] . \mathrm{H} \quad$ owever, nontraditional instructional practices such as problem-based learning are more explicitly designed to develop student attitudes and skills relevant to SDL, and there is some literature support to suggest that these approaches are more effective at developing selfdirected learners [9]. There rem ains, how ever, little em pirical data on those factors that promote SDL amongst undergraduate engineering students, especially from carefully designed studies using validated instrum ents. This $\mathrm{m}$ ultiyear investigation seeks to fill that gap by conducting an observational study that examines a range of engineering environments, carefully characterizes instructor practices regarding support of student autonomy, and analyzes the relationship between classroom environments and proxies for lifelong learning such as SDL behaviors and attitudes. 


\section{BACKGROUND}

\section{A. Defining Self-Directed Learning}

One of the greatest challenges associated with SDL lies in its definition. Some engineering educators may consider it as a single skill that individuals either have or lack. In reality, the building of SDL aptitude involves a complex interplay among nearly every aspect of human development. Individuals become self-directing through mastery of a broad range of skills, attitudes, and know ledge [10-17]. The education literature includes extensive discussion of the com petencies and attitudes of effective self-directed learners [18-21] and descriptions of the many factors that affect student growth in autonomous learning environm ents. These include cognitive and metacognitive factors [11,22] $m$ otivational factors [11,23], behavioral components [24,25] and contextual and social aspects of learning [22,26-30].

Motivational, cognitive, behavioral, and contextual factors are clearly interrelated, and the support of the development of students to becom e self-directed learners relies on a com plex balancing of these factors in the classroom. For example, much is known about the relationship between student self-direction and motivation, and about the im portance of fostering positive student attitudes and behaviors for engagem ent in SD L environments. Autonomy has been shown to increase students' intrinsic motivation, self-efficacy, and perceptions of task value [31-33], and use of cognitive and $m$ etacognitive strategies for learning and adaptive motivational strategies [34]. Black and Deci further demonstrated that autonomy-oriented students had higher perceived competence, higher interest and enjoyment, and lower anxiety and grade-focused goals [27]. Zimmerman emphasized that in addition to $\mathrm{m}$ etacognitive skill $\mathrm{s}$, students need a sense of self-efficacy and personal agency for success in self-directed environments [35].

\section{B. Role of Instructor in Self-Directed Learning}

Although much of the burden of developing SDL competence falls on students, instructors also play a critical role in effectively promoting individual SDL development both through their instructional choices and their interactions with students. Autonomy support is one such area in which different practices may yield different outcomes. Black and Deci, in their investigation of undergraduate students in organic chemistry, revealed that student s' perceived instructor support of autonomy related to improved perceptions of competence, interest and enjoym ent, and ability to self-regulate [27]. Opportunities for individual choice, control, authority, and responsibility appear to be im portant elem ents in both the academic achievement and the psychological development of students.

Table I, developed by Stefanou et al. [28], provides a framework for characterizing different types of autonomy support that may help develop students ' self-directed learning, along with examples of specific in structor strategies. In this framework, Organizational Autonomy Support includes student choices that are primarily related to contextual factors (e.g., selection of team members) and behavioral factors (e.g., managing due dates). Procedural Autonomy Support includes choices related to students' intrinsic $m$ otivations (e.g., discussing their wants and displaying individual work), and some opportunities that connect $\mathrm{m}$ otivational and cognitive strategies (e.g., selection of resources). The $\mathrm{C}$ Autonomy Support describes choices that relate directly to students' mental processes duri ng learning (e.g., self-reflection on errors, consideration of multiple solutions and strategies).

TABLE I. STRATEGIES ASSOCIATED WITH THE DifFERENT FEATURES OF AUTONOMY SUPPORT

\begin{tabular}{|c|c|c|}
\hline $\begin{array}{c}\text { Organizational } \\
\text { Autonomy Support }\end{array}$ & $\begin{array}{c}\text { Procedural Autonomy } \\
\text { Support }\end{array}$ & $\begin{array}{c}\text { Cognitive Autonomy } \\
\text { Support }\end{array}$ \\
\hline $\begin{array}{l}\text { Students are given } \\
\text { opportunities to: } \\
\text { - Choose group } \\
\text { members } \\
\text { - Choose evaluation } \\
\text { procedure } \\
\text { - Take responsibility } \\
\text { for due dates } \\
\text { - Help create class } \\
\text { policies }\end{array}$ & $\begin{array}{l}\text { Students are given } \\
\text { opportunities to: } \\
\text { - Choose how } \\
\text { competence is } \\
\text { demonstrated } \\
\text { - Display individual } \\
\text { work } \\
\text { - Discuss their wants } \\
\text { - Choose resources to } \\
\text { use }\end{array}$ & $\begin{array}{l}\text { Students are given } \\
\text { opportunities to: } \\
\text { - Discuss multiple } \\
\text { approaches } \\
\text { - Find multiple } \\
\text { solutions } \\
\text { - Justify solutions } \\
\text { - Be independent } \\
\text { problem solvers } \\
\text { - Reevaluate errors } \\
\text { - Debate ideas freely } \\
\text { - Have less teacher } \\
\text { talk time; more } \\
\text { teacher listening }\end{array}$ \\
\hline
\end{tabular}

Unfortunately, there is little solid em pirical data that shows how instructor choices promote or hinder SDL development in undergraduate engineering students. Of the many factors that contribute to the student response in autonomous learning environments, perhaps the least explored are the contextual o $r$ environmental factors. In $2000 \mathrm{~Pa}$ ul R. Pintrich noted that "there is a clear need for more descriptive, ethnographic, and observational research on how different features of the context can shape, facilitate, and constrai n self-regulated learning [13]. Nearly a decade later, the need remains. Studies have shown that students' positive perceptions of their assigned tasks and instructors' autonomy support can 1 ead to increases in intrinsic motivation, self -regulation, perceived competence, interest, engagement, and academic performance [34,36,37], but the connections between these student perceptions and the instructors' choices in course design and classroom environments remain unclear.

Clearly, there exists an opportunity for researchers to identify approaches, interventions, interactions, and contexts that prom ote the developm ent of SD L skills in undergraduate students. In particular, there is a need to provide a deeper understanding of the relationship between the types of student autonomy support and the development of SDL competencies. Our study w ill aid instructors' understanding of how their classroom practices affect a range of student outcomes related to lifelong learning. W e expect that variations in ways that instructors support student aut onomy wi ll influence students' development as self-directed learners. We aim to gain a clearer understanding of how aspects of course design and implementation relate to student responses and learning outcomes by exploring these questions:

1. In what ways do engineering instructors assist students to become self-directed learners? Are there instructor practices 
and behaviors that lead to great er student involvement in and ownership of their own learning?

2. What are students' behavioral and affective responses to different ways autonomy is supported in undergraduate engineering settings?

3. What effect does a sense of autonomy have on students' perceptions of their own learning?

\section{Methodology}

A variety of different undergraduate engineering course environments $w$ ill be exam ined as part of this study. The courses span nearly all academic levels, include both lecture and laboratory settings, and provide a range of pedagogical strategies that emphasize active, collaborative, problem-based learning, and project-based 1 earning. This study focuses on active learning environments since these have provided the most promising results to date for developing students' capacity for self-directed learning.

Although all of the classroom settings may be characterized as "active," the different courses w ill present recognizable differences in the types and amounts of student choice and control, as well as differences in the classroom environment characterized in terms of stude nt-student and student -faculty interactions in support of student autonomy. As such, these courses provide an opportunity to study the relationships between differences in autonomy support on the development of SDL-related competencies of motivation, student autonomy, and cognitive and $\mathrm{m}$ etacognitive strategy use. $\mathrm{W}$ e anticipate the different courses $\mathrm{w}$ ill provide $\mathrm{w}$ ide variety in the type and level of organizational, procedural and cognitive student autonomy support. The rigorous characterization of the classroom environment with respect to student autonomy support is the first phase of the evaluation component of this project and is the focus of this paper.

A selection of class sessions for each of the instructors $w$ ill be studied intensively through the lens of autonomy-supportive practices. To do this, syllabi and classroom artifacts in the form of classroom assignm ents w ill be collected, selected class sessions will be videotaped, and the instructors w ill complete a survey that $m$ easures personal epistem ology. Students $w$ ill be asked to complete a survey that measures the aspects of motivation, autonom $\mathrm{y}$, and cognitive and $\mathrm{m}$ etacognitive strategy use that are associated with SDL at the beginning of the sem ester and again at the end, and students $\mathrm{w}$ ill be videotaped along with their inst ructor during preselected class sessions. At the com pletion of the course, the instructors $\mathrm{w}$ ill be interviewed to discuss the choices they m ade in their course and students $\mathrm{w}$ ill be interview ed to discuss how those choices affected the variables of interest in this study.

\section{WORK IN PROGRESS}

We are in the first year of this three-year study, and are beginning the process of charact erizing our various classroom environments. W e w ill report on prelim inary findings at the conference. Here we describe the various courses and characterization methods in this first year.

\section{A. Descriptions of Courses}

Heat and $\mathrm{M}$ ass Transfer is a required course for third year chemical engineering students. It adopts a problem-based learning structure in which students work in teams to solve a variety of open-ended, releva nt engineering problems. Students are provided limited organizational autonomy support (they have some influence of team members and due dates) and more significant procedural autonomy support (they have significant influence on the selection of resources and regular opportunities to discuss their $\mathrm{w}$ ants). In addition, the course incorporates very substantial cognitive autonom y support elements in that students are engaged in regular discussions of multiple approaches and solutions to problem $\mathrm{s} \mathrm{w}$ ith heavy course emphasis on justifying their solutions and exhibiting independent problem solving strategies.

Circuits is a sophomore-level course for electrical, industrial and mechanical engineering majors. Faculty -student interactions occur primarily during class lec ture periods. In a typical class period, the professor prepares notes in PowerPoint which are projected using a Tabl etPC. The notes are intended to provide the outline and structure for the discussion of the topic, and there are many spaces where students are encouraged to write in their own notes, answers to questions or solutions to problems. Students are often asked questions to be sure that they are following, and they are called on in order going around the room to be sure that everyone is involved. In short, there is a reasonable amount of faculty -student interaction during these tim es but little student -student interaction during this time.

Most periods of the Circuits course also include at least one activity for $\mathrm{w}$ hich the problem statem ent is included in the notes along with whatever supporting information is necessary. Students are told to "turn to a helpful neighbor" and work out their solution. Students then work together on the problems while the professor walks around the room and checks in with groups, asks questions or answers questions. During this time, there is a fair amount of faculty-student interaction and studentstudent interactions within their groups. Finally, there are significant student-student interactions in cooperative -learning homework teams. Three to four students are assigned to each team at the beginning of the semester and each team meets weekly to work on the week's assignment. Team members rotate through various roles on the team and submit one solution set.

Failure Analysis and Prevention is a project -based, upperlevel elective course for engineering students. Student development in the course is focused on professional -level competencies and application of self-directed learning skills. By organizing and carrying out self-directed failure investigations of real -world components and systems, and through analysis of published case studies students learn failure analysis by doing failure analysis. The projects emphasize the interdisciplinary nature of failure investigations, and they provide students with the opportunity to select team members and due dates (organizational autonomy), identify resources and express their own goals (procedural autonomy), and select learning strategies, manage class time, align lea rning with their own goals, and self-assess their project work as well as their 
development as a team member and lifelong learner (cognitive autonomy). Throughout the projects, the instructor serves as a consultant and a sounding board for students' experimental strategies and data analyses. Some of the class periods are devoted to open-ended discussions and debates of contextual factors that contribute to engin eering decision-making. In the first half of the semester, the instructor provides weekly reading assignments and facilitates an in-class discussion of the readings. In the second half of the semester, student teams take responsibility for the selection of readings and facilitation of the in-class discussions.

The final course under study in the firs Thermodynamics II, is a required course for $\mathrm{m}$ echanical engineering students. The course is taught in a lecture format with homework sets, quizzes, and midterm and final exam. It relies on the least amount of formal team work both in and out of class, and opts instead for peer teams formed ad hoc during class meetings. The instructor uses active-learning techniques during class, including the use of clickers and "turn-to-yourneighbor and discuss." Outside of class, students are highly encouraged to work in small groups to complete the assignments, but each student is expected to submit homework, if he or she elects to do so. In addition to active learning techniques, the instructor makes available partially completed notes, and incorporates some conceptual questions (using the clickers) to get away from focusing only on calculation-based examples. A typical class includes a brief lecture (less than $10 \mathrm{~min}$ ) and quickly moves to problem solving. The instructor sets up the problem (describing $i t$, providing known values, etc.) and breaks it into small 'chunks' or steps, w hich is then turned over to the students to solve individually. The students' understanding is then checked using the clickers. W hen there is some confusion as to the correct answer, students form impromptu two-person teams to discuss the question, and then are retested using the clickers. This procedure is repeated until the problem is com pleted, at which point a new problem or topic is begun.

\section{B. Evaluation Methodology}

A m ixed-method approach $w$ ill be used to exam ine how instructors support and facilitate student autonom y and other outcomes associated with SDL, such as motivation and cognitive and $m$ etacognitive strategy use. The evaluation plan includes:

- Characterizing the learning environment within the chosen engineering courses with respect to support of student autonomy and authority

- Using surveys to collect data on student outcomes relevant to lifelong learning in the diverse classroom environments

- Conducting focus groups with student to develop a deeper understanding of emergent themes in the student responses to instruction in the different course settings

- Conducting semi-structured, open-ended instructor interviews to develop a deeper understanding of the instructors' rationales for instructional decisions $w$ ith respect to objectives associated with supporting student outcomes associated with lifelong learning

Each of these elem ents is described in $\mathrm{m}$ ore detail below, and a summary of the evaluation goals and assessment tools is shown in Table II.

\section{1) Characterizing the Learning Environment}

The classroom environment will be characterized according to the rubric developed by Stefanou et al. [28], which breaks student autonomy support into the three categories of organizational, procedural and cognitive autonom y support. This characterization of the classroom environm ents will use instructor course inform ation (e.g., syllabi and assignment descriptions), videotaped classroom observations of instructor student interactions, student surveys using the Learning Climate Questionnaire (LCQ) [39] and instructor surveys using the Epistemic Beliefs Inventory (EBI) [38]. In addition, student responses to the LCQ survey, focus groups and student dialogue from the videotaped class sessions $w$ ill be used to gauge students' perceptions of the degree to which the learning environment supported their sense of autonomy. This approach should provide for the creation of rich, contextualized descriptions of what instructors and learners do, how instructors and students relate to each other, and how students view their classroom environments.

\section{2) Assessment of SDL Outcomes}

Students' capacity for SDL, defined in terms of motivation, autonomy, and cognitive and $\mathrm{m}$ etacognitive strategy use $\mathrm{w}$ ill be measured at the start and end of the term using an available validated survey instrum ent (M SLQ) [40]. T his instrum ent provides the opportunity to correlate differences in relevant outcomes with specific instructor practices and classroom environments. Multivariate analyses of variance will be used to evaluate the effects of time and the independent environmental variables on the $\mathrm{m}$ ultiple dependent variables such as student cognitive strategy use, self-efficacy, and $\mathrm{m}$ otivation. $\mathrm{C}$ ausal model or path analysis w ill be used to build a $\mathrm{m}$ odel that describes how different instructor approaches lead to different student psychological outcom es. This m odel development will include determ ination of the correlations betw een instructor approach and student outcomes, and between and among the dependent variables. Cronbach's $\alpha$ values will be calculated to determine reliability and tem poral stability of the quantitative assessment data. Inter-rater reliability estim ates $\mathrm{w}$ ill be calculated to determine the degree of rater agreement on the data coded for autonomy support.

Student focus groups and instructor interview s will be used to develop a deeper understanding of emergent themes in the student responses to varying levels of learning autonomy in the different course settings and instructional decision-making. The design of the form al interview protocol will be guided by the classroom observations and survey results, but possible areas of focus include students' and instructors' goal-setting and planning; student monitoring and self-evaluating of learning; instructors' environmental structuring; self-view as an autonomous learner and instructor; affective responses to choice and control; internalization of learning goals; time and effort management; active help-seeking; and reflections on learning and behaviors. 
TABLE II. OVERVIEW OF ProJect GoAls AND Assessment TOOLS

\begin{tabular}{|c|c|}
\hline Project Goal & Assessment data and Evaluation Tools \\
\hline $\begin{array}{l}\text { Characterize the classroom } \\
\text { environment with respect } \\
\text { to student autonomy } \\
\text { support }\end{array}$ & $\begin{array}{l}\text { - Course information (syllabi and } \\
\text { assignments coded for task, procedural or } \\
\text { cognitive autonomy support) } \\
\text { - Classroom observations (videotaped and } \\
\text { analyzed by coding for task, procedural or } \\
\text { cognitive autonomy support) } \\
\text { - Instructor surveys (Epistemic Beliefs } \\
\text { Inventory [38] will be completed and } \\
\text { correlations calculated between scores on } \\
\text { this instrument and type of autonomy } \\
\text { support practiced as determined on the } \\
\text { basis of the coded data from videotapes } \\
\text { and artifacts) } \\
\text { - Student surveys (Learning Climate } \\
\text { Questionnaire [39]) } \\
\text { - Student statements from videotaped } \\
\text { classroom sessions, coded for evidence of } \\
\text { statements associated with autonomy } \\
\text { beliefs } \\
\text { Instructor interviews recorded and } \\
\text { analyzed for reflection on teaching } \\
\text { practices that support autonomy } \\
\text { - Student focus groups videotaped and } \\
\text { analyzed for consistency with observations } \\
\text { from videotaped class sessions }\end{array}$ \\
\hline $\begin{array}{l}\text { Assessment of SDL } \\
\text { outcomes } \\
\text { - Cognitive and } \\
\text { metacognitive strategy } \\
\text { use }\end{array}$ & $\begin{array}{l}\text { - Student completion of Motivated } \\
\text { Strategies for Learning Questionnaire } \\
\text { (MSLQ) [40] }\end{array}$ \\
\hline - Motivation & - Student completion of MSLQ \\
\hline - Autonomy & - Student completion of MSLQ \\
\hline $\begin{array}{l}\text { - Behavioral regulatory } \\
\text { strategy use }\end{array}$ & - Student completion of MSLQ \\
\hline
\end{tabular}

Analyses will involve transcription of all interview data and audio/video recordings; coding of interview transcriptions; and comparison of coded data to frameworks for SDL. Correlation analyses $\mathrm{w}$ ill illum inate the existence and strength of relationships between instruction and a range of outcomes tied to SDL. Based on the proposed assessment tools, we expect to identify correlations between the type and degree of instructor support of student autonomy, authority, and feelings of competence and students' motivation, self -efficacy, selfregulation, perceptions of the e nvironment, and perceptions of lifelong learning competency development.

\section{3) Summary of Evaluation Plan}

The mixed qualitative and quantitative approach proposed in this study w ill enable exam ination of how the instructors' choices regarding support of student autonomy in courses may affect the classroom clim ate and ultim ately students development as self-directed 1 earners. The results from the proposed investigation $\mathrm{w}$ ill be a valuable resource for all engineering educators who strive to help their students develop lifelong learning skills and ultim ately enable them to be successful in their careers.

\section{ACKNOWLEDGMENT}

This material is based upon work supported by the US National Science Foundation under Grant Nos. EEC-0835884, EEC-0835889, EEC-0835901, and EEC-0835911.

\section{REFERENCES}

1. American Society for Engineering Education Deans Council and Corporate Roundtable, "The Green Report: Engineering Education for a Changing World" (Washington, D.C.: ASEE, 1994).

2. National Research Council's Board on Engineering Education, "Engineering Education: Designing an Adaptive System" (Washington, D.C.: National Academy Press, 1995).

3. Peden, I.C., E.W. Ernst, and J.W. Prados, "Systemic Engineering Education Reform: An Action Agenda" (Washington, D.C.: National Science Foundation, 1995).

4. The Engineer of 2020: Visions of Engineering in the New Century. (National Academy Press (U.S.), Washington DC, 2004).

5. G. Clough, Educating the Engineer of 2020: Adapting Engineering Education to the New Century. (National Academy of Engineering, Washington, DC, 2005).

6. Criteria for Accrediting Engineering Programs, Accreditation Board for Engineering and Technology Engineering Accreditation Commission (2005). Available at http://www.abet.org/forms.shtml.

7. Litzinger, T., Wise, J., Lee, S., Bjorkund, S. (2003) “ Assessing Readiness for Self - directed Learning”, Proceedings, ASEE Annual Conference and Exposition, Retrieved from http://www.asee.org/acPapers/2003 - 1429_Final.pdf, 2 July 2003.

8. Fowler, D., Maxwell, D., and Froyd, J., (2003) "Learning Strategy Growth Not What Expected After Two Years through Engineering curriculum", Proceeding, ASEE Annual Conference \& Exposition, Retrieved from http://www.asee.org/acPapers/2003 - 534_Final.pdf, 2 July 2003.

9. Blumberg, B., "Evaluating the Evidence that Problem-Based Learners are Self-Directed Learners: A Review of the Literature, " in D.H. Evensen and C.E. Hmelo, eds., Problem - Based Learning: A Research Perspective on Learning Interactions, Mahwah, NJ: Erlbaum, 2000, pp. 199-226.

10. Skager, R., “ Self-Directed Learning and Schooling: Identifying Pertinent Theories and Illustrative Research, ” International Review of Education 25, 4517 - 543 (1979).

11. Pintrich, P. R., and E. V. De Groot, “Motivational and Self-Regulated Learning Components of Classroom Academic Performance, ” Journal of Educational Psychology 82133 - 40 (1990).

12. Zimmerman, B. J., and A. Kitsantas, “Developmental phases in self regulation: Shifting from process goals to outcome goals, ” Journal of Educational Psychology 8929 - 36 (1997).

13. Pintrich, P. R., "The role of goal orientation in self - regulated learning,” In M . Boekaerts, P. R. Pintrich, and M . Zeidner (Eds.), Handbook of Self - Regulation (San Diego, CA: Academic, 2000) 451 - 502 .

14. Zimmerman, B. J., “Development of self - regulated learning: Which are the key subprocesses? " Contemporary Educational Psychology 16 $307-313$ (1986).

15. Knowles, M., Self-Directed Learning: A Guide for Learners and Teachers (Chicago: Association Press, Follett Publishing Company, 1975).

16. Zimmerman, B. J., Self-Regulated Learning and Academic Achievement: An Overview, Educational Psychologist $2513 \quad-17$ (1990).

17. Rogers, C. R., Freedom to Learn: A View of What Education Might Become (Columbus, OH: Charles E. M errill Publishing Company, 1969).

18. Candy, P., Self-Direction for Lifelong Learning: A Comprehensive Guide to Theory and Practice (San Francisco, Cal.: Jossey - Bass, 1991) 
19. Hung, W., J. H. Bailey, D. H. Jonassen, "Exploring the Tensions of Problem-Based Learning: Insights from Research. ” In D. S. Knowlton and D. C. Sharp (eds.), Problem-Based Learning in the Information Age, New Directions for Teaching and Learning, 95, 13 - 23 (San Francisco: Jossey - Bass, 2003).

20. MacKinnon, M. M. “ CORE Elements of Student Motivation in Problem-Based Learning.” In M. Theall (ed.), Motivation from Within Approaches for Encouraging Faculty and Students to Excel. New Directions for Teaching and Learning, 78, 49 - 58 (San Francisco: Jossey - Bass, 1999).

21. Knowles, M., Self-Directed Learning: A Guide for Learners and Teachers (Chicago: Association Press, Follett Publishing Company, 1975).

22. Zimmerman, B. J., Attaining Self-Regulation: A Social Cognitive Perspective. In M . Boekaerts, P. R. Pintrich, and M . Zeidner (Eds.), Handbook of Self - Regulation (San Diego, CA: Academic, 2000) 13 39 .

23. Zimmerman, B. J., A. Bandura, and M. Martinez-Pons, "SelfMotivation for Academic Attainment: The Role of Self - Efficacy Beliefs and Personal Goal Setting, " American Educational Research Journal 293663 - 676 (1992)

24. Salomon, G. and D. N. Perkins, "Individual and Social Aspects of Learning," Review of Research in Education 231 - 24 (1998).

25. Patrick, H., and M. J. Middleton, "Turning the Kaleidoscope: What We See When Self - Regulated Learning is Viewed with a Qualitative Lens," Educational Psychologist 37127 - 39(2002).

26. Pilling - Cormick, J., " Transformative and Self-Directed Learning in Practice," New Directions for Adult and Continuing Education 7469 77 (1997).

27. Black, A. E., and E. L. Deci, "The Effects of Instructors' Autonomy Support and Students' Autonomous Motivation on Learning Organic Chemistry: A Self-Determination Theory Perspective, " Science Education 847740 - 756 (2000).

28. Stefanou, C. R., K. C. Perencevich, M. DiCintio, and J. C. Turner, "Supporting Autonomy in the Classroom: Ways Teachers Encourage Student Decision Making and Ownersh ip," Educational Psychologist 39 297 - 110 (2004)

29. Assor, A., H. Kaplan, and G. Roth, "Choice is Good, but Relevance is Excellent: Autonomy-enhancing and Suppressing Teacher Behaviours Predicting Students' Engagement in Schoolwork, ” British Journal of Educational Psychology 72261 - 278 (2002).
30. Evensen, D. H., J. D. Salisbury-Glennon, and J. Glenn, “A Qualitative Study of Six Medical Students in a Problem-Based Curriculum: Toward a Situated Model of Self-Regulation, Journal of Educational Psychology 934659 - 676 (2001)

31. Ryan, R. M ., and E. L. Deci, "Self-Determination Theory and the Facilitation of Intrinsic M otivation, Social Development, and W ell Being," American Psychologist 55168 - 78 (2000).

32. Deci, E. L., and R. M. Ryan, "The "What" and "Why" of Goal Pursuits: Human Needs and the Self - Determination of Behavior, Psychological Inquiry 114227 - 268 (2000).

33. Garcia, T., and P. R. Pintrich, "The Effects of Autonomy on Motivation and Performance in the College Classroom, " Contemporary Educational Psychologist 214477 - 486 (1996).

34. VanderStoep, S. W ., P. R. Pintrich, and A. Fagerlin, "Disciplinary Differences in Self-Regulated Learning in College Students, Contemporary Educational Psychology 21345 - 362 (1996).

35. Zimmerman, B. J., "Self-Regulation Involves More Than Metacognition: A Social Cognitive Perspective,” Educational Psychologist 304217 - 221 (1995).

36. Noels, K. A., R. Clement, and L. G. Pelletier, "Perceptions of Teachers' Communicative Style and Students' Intrinsic and Extrinsic Motivation," The Modern Language Journal 83 (i) 23 - 34 (1999).

37. Kaplan, H., Assor, A., \& Roth, G.. Effects of autonomy support and competence support on academic functioning. Paper presented at the 8th Workshop on Achievement and Task Motivation, Moscow, Russia (2002).

38. Schraw, G, Bendixen, L. D., \& Dunkle, M. E., Development and validation of the Epistemic Beliefs Inventory. In Hofer, B. K. \& Pintrich, P.R. (eds) Personal Epistemology: The psychology of beliefs about knowledge and knowing (Mahwah, New Jersey: Lawrence Erlbaum Associates, 2002)

39. Williams, G. C., \& Deci, E. L., Internalization of biopsychosocial values by medical students: A test of self-determination theory. Journal of Personality and Social Psychology 70767 - 779 (1996).

40. Pintrich, P. R., Smith, D. A. F., Garcia, T., \& McKeachie, W. J., A manual for the use of the Motivated Strategies for Learning Questionnaire (MSLQ) (Ann Arbor, MI: National Center for Research to Improve Post - Secondary Teaching, 1991). 